\title{
AKSElerASI:
}

JURNAL PENDIDIKAN GURU MI

Volume 1, Nomor 2, Desember 2020, Hal. 94-111

\section{NILAI-NILAI PENDIDIKAN KARAKTER DALAM NOVEL ANAK- ANAK LANGIT UNTUK MEMBINA KARAKTER SISWA DI MADRASAH IBTIDAIYAH}

\author{
Fika Fauliyah \\ UIN Sunan Gunung Djati Bandung, Jalan A.H Nasution No.105 Cibiru Kota Bandung \\ e-mail: fikafauliyah15@gmail.com
}

\begin{abstract}
The purpose of this study is to describe the character values in the novel Anak-Langit by Mohd Amin MS and to foster and apply character to students of MI, because it is seen from the phenomena that occur in Indonesia today such as the occurrence of bad habits, fighting, cheating, dishonesty, and disrespect for parents. This study uses a qualitative approach, with content analysis methods. The type of research used is literature study. The technique of collecting data is documentation study, which means that the data used can be done by examining children's novels from heaven and looking for relevant documents or books and literature. The data analysis techniques used are data reduction, data presentation and conclusion / verification. Based on the results of this study, it shows that there are 18 characters in the novel Anak-Langit, namely religious, honest, responsibility, discipline, hard-working, creative, independent, curiosity, fond of reading, respect for achievement, democratic, social care, friendly. communicative, tolerant, spirit of nationality, love the country, love peace, and care for the environment. As for implementing these 18 characters, it is in activities or programs provided in the school environment such as extracurricular, intraculricular and other routine activities that can be used as a habit for MI.
\end{abstract}

Keyword: Value of Character Education, Novel Anak-anak Langit, Madrasah Ibtidaiyah

\begin{abstract}
ABSTRAK
Tujuan dari penelitian ini adalah untuk mendeskripsikan nilai-nilai karakter yang ada dalam novel Anak-anak Langit Karya Mohd Amin MS serta untuk membina dan menerapkan karakter kepada siswa MI, karena dilihat dari fenomena yang terjadi di Indonesia saat ini seperti terjadinya kebiasaan-kebiasaan buruk, perkelahian, menyontek, tidak jujur, dna tidak menghormati orangtua. Penelitian ini menggunakan pendekatan kualitatif, dengan metode analisis isi. Jenis penelitian yang digunakan adalah studi kepustakaan. Teknik pengumpulan data dengan studi dokumentasi yang artinya data-data yang digunakan dapat dilakukan dengan menelaah novel anak-anak langit dan mencari dokumen atau buku yang relevan dan studi pustaka. Adapun teknik analisis data yang digunakan adalah reduksi data, penyajian data dan penarikan kesimpulan/verifikasi. Berdasarkan hasil penelitian ini menunjukkan ada 18 karakter yang ada didalam novel Anak-anak Langit yaitu religius, jujur, tanggung jawab, disiplin, bekerja keras, kreatif, mandiri, rasa ingin tahu, gemar membaca, menghargai prestasi, demokratis, peduli sosial, bersahabat/komunikatif, toleransi, semangat kebangsaan, cinta tanah air, cinta damai, dan peduli lingkungan. Adapun dalam menerapkan ke-18 karakter ini adalah dalam kegiatan-kegiatan atau program-program yang disediakan di lingkungan sekolah seperti ekstrakulikuler, intrakulikuler serta kegiatan-kegiatan rutin lainnya yang dapat dijadikan kebiasaan untuk siswa MI.
\end{abstract}

Kata Kunci: Nilai Pendidikan Karakter, Novel Anak-anak Langit, Madrasah Ibtidaiyah PENDAHULUAN 
Pendidikan adalah usaha seseorang untuk mencerdaskan bangsa, dan merupakan suatu hal yang tidak dapat dilepaskan dalam kehidupan manusia, karena pendidikan suatu hal yang sangat penting yang harus dimiliki oleh setiap manusia. Menurut Syah (2010) pendidikan diartikan juga sebagai sebuah cara atau jalan dengan menggunakan metode-metode tertentu sehingga seseorang dapat memperoleh sesuatu yang baru baik dalam pengetahuan, pemahaman, serta bagaimana cara bertingkah laku sesuai dengan kebutuhan yang diperlukan. Dalam undang-undang No. 20 Tahun 2003 Bab 2 Pasal 3 tentang sistem pendidikan nasional menyatakan bahwa: Pendidikan nasional berfungsi mengembangkan kemampuan dan membentuk watak serta peradaban bangsa yang bermartabat dalam rangka mencerdaskan kehidupan bangsa, bertujuan untuk berkembangnya potensi peserta didik agar menjadi manusia yang beriman dan bertaqwa kepada Tuhan Yang Maha Esa, berakhlak mulia, sehat, berilmu, cakap, kreatif, mandiri dan menjadi warga negara yang demokratis serta bertanggunng jawab. Dilihat dari definisi yang disampaikan oleh Undang-undang dapat dikatakan bahwa pendidikan karakter merupakan hal yang sangat penting yang harus ada dalam diri siswa.

Pendidikan karakter merupakan hal yang paling utama yang harus diterapkan pada setiap diri peserta didik, karena pendidikan karakter ini diharapkan mampu menjadi sebuah pondasi utama dalam membentuk generasi bangsa yang berkualitas (Nopan, 2015). Sehingga pengembangan budaya dan karakter ini dapat dilakukan dalam sebuah proses pendidikan yang tidak membebaskan siswa dari lingkungan-lingkungan sosial dan budaya (masyarakat, bangsa). Pendidikan karakter merupakan suatu kebutuhan yang diperlukan masyarakat saat ini untuk membantu menjadikan manusia yang tidak hanya memiliki kecerdasan otak namun juga memiliki karakter atau watak yang mampu membawa generasi-generasi bangsa menjadi pribadi yang baik dan berkualitas.

Masalah yang terjadi di Indonesia sangatlah rumit sehingga perlu adanya penyelasaian dan jika dilihat dari fenomena-fenomena yang terjadi saat ini seperti terjadinya perkelahian antar pelajar, kebiasaan buruk menyontek, tidak menghargai orangtua, dan tidak adanya sikap hormat kepada sesama maka perlu adanya perbaikan atau perubahan dalam diri siswa (Utomo \& Muntholib, 2018). Pembelajaran sastra khususnya novel memberikan banyak manfaat dalam proses pembentukan karakter siswa, karena didalam sastra terdapat empat manfaat yang dapat diambil yaitu membantu kelancaran siswa dalam berbahasa, menumbuhkan dan mengembangkan pemahaman dalam kultur, meningkatkan rasa karsa, serta dapat membentuk tingkah laku, kerpibadian ataupun akhlak (Ernawati, 2019).

Pentingnya penelitian ini, karena peneliti melihat kondisi-kondisi yang terjadi di Indonesia saat ini, dan mulai berkurangnya akhlak dan moral yang baik yang ada pada diri siswa. Oleh karena itu, pendidikan karakter merupakan hal yang sangat penting yang harus ada dalam manusia khususnya siswa. Dan salah satu sumber yang dapat merubah dan menanamkan pendidikan 
karakter adalah novel yang memberikan pelajaran dan memberikan nilai pendidikan karakter bagi para pembacanya adalah novel anak-anak langit karya Mohd Amin MS yang menceritakan tentang cerita-cerita yang bertajuk religius, yang menginspirasi serta memiliki makna dibalik cerita serta kutipan-kutipan yang ada dalam novel. Dan penelitian ini dimaksudkan untuk melihat nilainilai pendidikan karkater yang ada didalam novel Anak-anak Langit Karya Mohd Amin MS dan untuk mendeskripsikan nilai-nilai pendidikan karakter apa saja yang ada didalam novel tersebut serta bagaimana menerapkannya kepada siswa khususnya pada siswa di Madrasah Ibtidaiyah (MI). Sehingga dalam penelitian akan membahas mengenai hal-hal yang berkaitan dengan nilai pendidikan karakter dalam novel Anak-anak Langit.

\section{METODE}

Metode penelitian yang digunakan adalah metode analisis isi atau konten analisis, menurut Weber dikutip dari Shidiq \& Choiri (2019) analisis isi atau konten adalah sebuah metode penelitian dengan menggunakan seperangkat prosedur untuk membuat inferensi yang valid dari teks. Metode yang digunakan dalam penelitian adalah metode analisis konten (content analysis) yaitu penelitian yang mana sifat dari pembahasannya adalah mendalami isi suatu informasi yang tertulis ataupun tercetak dari dalam media massa. Sehingga analisis konten adalah sebuah teknik yang digunakan dalam penelitian untuk menganalisis serta memahami isi teks, atau teknik penyelidikan yang mana untuk menguraikan suatu objektif. Dalam penelitian ini peneliti mengkaji tentang nilai-nilai pendidikan karakter dalam novel anak-anak langit karya Mohd Amin MS. Pendekatan yang digunakan adalah pendekatan kualitatif, menurut Bodgan dan Taylor penelitian kualitatif yaitu penelitian yang bermaksud menggunakan data deskriptif berupa kata-kata tertulis maupun lisan dari perilaku yang akan diamati atau sedang diamati (Wandi \& Nurhasono, 2013).

Jenis penelitian yang digunakan adalah Library Research (Studi Kepustakaan). Menurut Mardalis studi kepustakan adalah studi yang mana memerlukan sebuah bantuan yang tujuannya digunakan untuk mengumpulkan data dan informasi dari berbagai material seperti buku-buku, majalah, dokumen, kisah-kisah ataupun majalah (Mirzaqon \& Purwoko, 2018). Adapun teknik pengumpulan data yang digunakan dalam penelitian ini yaitu: pertama adalah studi pustaka yang mana menurut Nazir Studi pustaka yang disebut juga dengan studi literatur merupakan salah satu teknik pengumpulan data dengan menggunakan cara membaca, dengan berbagai sumber atau referensi seperti buku teks, jurnal (tulisan ilmiah yang berisi tulisan ilmiah dan hasil-hasil dari seminar) dan perodical (majalah yang biasa diterbitkan oleh lembaga-lembaga pemerintah). Kedua adalah studi dokumentasi yang artinya dapat diperoleh dari informasi yang bukan hanya dari orang sebagai narasumber, namun dapat diperoleh dari informasi sumber secara tertulis atau dokumen yang ada pada informan dalam berbagi bentuk peninggalan seperti karya seni, budaya dan karya berpikirnya (Syukwansyah, 2016). 
Adapun langkah-langkah yang dilakukan peneliti dalam menganalisis data (Sugiyono, 2017), yaitu : Pertama, reduksi data yaitu meringkas, memilih hal-hal yang utama, fokus pada halhal yang penting, dicari tema dan polanya dan membuang yang tidak perlu. Kedua, penyajian data yaitu setelah data di reduksi, maka langkah selanjutnya adalah dengan mendisplay data. Data penelitian kualitatif, penyajian data dapat dilakukan dengan berbagai bentuk seperti dalam bentuk deskripsi singkat, bagan atau grafik, hubungan antar kategori, bagan alur (flowchart) dan sejenisnya. Dan yang terakhir adalah kesimpulan atau verifikasi yang artinya setelah kedua langkah dilakukan, lalu disimpulkan.

\section{HASIL DAN PEMBAHASAN}

\section{Pengertian Nilai Pendidikan Karakter}

Nilai adalah suatu konsep keyakinan yang diyakini oleh seseorang bahwa apapun jika dilihat atau dipandang merupakan sesuatu yang berharga, dan apa yang dilihat itu merupakan sesuatu yang mengarahkan kepada sikap dan tingkah laku. Nilai merupakan hal yang sangat penting dan berguna bagi manusia, nilai adalah sesuatu yang sangat dihargai setiap manusia karena dengan nilai seseorang dapat menemukan kepuasaan dalam hidupnya dan objek dari nilai itu adalah tingkah laku atau perilaku seseorang (Gusal, 2015).

Pendidikan berarti membimbing seorang siswa atau seorang anak agar memiliki moral, kecerdasan serta mental yang kuat dan baik (Sholichah, 2018). Sehingga pendidikan adalah usaha seorang guru, orang tua serta masyarakat luar untuk membangun siswa atau anak didik agar tidak hanya memiliki kecerdasan intelektual saja, namun juga memiliki akhlak yang baik serta karakterkarakter baik yang seharusnya ditujukan oleh bangsa Indonesia.

Karakter merupakan sebuah watak, akhlak, perilaku ataupun etika yang baik maupun buruk yang sudah dimiliki sejak lahir ataupun dapat membenahi serta mengubahnya dengan keinginannya sendiri. Karakter ini tidak hanya identik dengan kepribadian ataupun akhlak, namun karakter ini juga sangat identik dengan moral dan etika seseorang, tidak hanya itu karakter adalah nilai-nilai tingkah laku seseorang yang secara universal meluruh semua aktivitas manusia baik aktivitasnya dengan Tuhan, diri sendiri, lingkungan maupun sesama manusia (Samrin, 2016).

Membicarakan tentang pendidikan karakter berarti membicarakan tentang kemajuan bangsa Indonesia, pendidikan karakter adalah hal yang sangat penting jika dibicarakan dan didengar saat ini karena orang yang memiliki karakter baik adalah orang yang memiliki akhlak, budi pekerti serta moral yang baik. Menurut Scereneo sendiri bahwa pendidikan karakter merupakan upaya yang dilakukan untuk mengembangkan kepribadian seseorang yaitu dari kepribadian positif melalui sikap teladan dengan mempelajari akhlak-akhlak baik atau akhlak Rasulullah, mengkaji dengan memahami lalu apa yang dilihat dan dipelajari dapat di praktikkan sehari-hari . 


\section{Nilai dalam Pendidikan Karakter}

Pusat Kurikulum Badan Penelitian dan Pengembangan Kementerian Pendidikan Nasional di dalam publikasinya yang berjudul Pedoman Pelaksanaan Pendidikan Karakter tahun 2011, telah mengidentifikasi 18 nilai pembentuk karakter yang mana merupakan hasil kajian dengan Pusat Kurikulum yang bersumber dari Agama, Pancasila, Budaya dan Tujuan Pendidikan Nasional (Putry, 2019).

Adapun deskripsi dari masing-masing nilai karakter yang telah dirumuskan dalam Pusat Kurikulum Badan Penelitian dan Pengembangan Kementerian Pendidikan Nasional, sebagai berikut:

Tabel 1. Daftar Nilai-nilai Karakter Berdasarkan Rumusan Kemendiknas

\begin{tabular}{|c|c|c|}
\hline No & Nilai Karakter & Deskripsi \\
\hline 1 & Religius & $\begin{array}{l}\text { Sikap dan perilaku yang patuh dalam melaksanakan ajaran agama yang } \\
\text { dianutnya serta toleran terhadap pelaksanaan agama lain. dan tujuan } \\
\text { adanya karakter religius adalah untuk mengembangkan kepribadian agar } \\
\text { tercermin perilaku yang sholeh dan sholehah. }\end{array}$ \\
\hline 2 & Jujur & $\begin{array}{l}\text { Sikap atau perilaku yang didasari dengan kepercayaan baik dalam } \\
\text { perkataan maupun perbuatan. Yang mana dengan adanya karakter jujur } \\
\text { ini terkesan untuk selalu berkata jujur tanpa adanya dusta, penipuan dan } \\
\text { lain sebagainya. }\end{array}$ \\
\hline 3 & Toleransi & $\begin{array}{l}\text { Sikap, perilaku dan tindakan yang menghargai setiap perbedaan baik itu } \\
\text { ras, suku, budaya, agama maupun pendapat orang lain yang berbeda dari } \\
\text { diri sendiri. }\end{array}$ \\
\hline 4 & Disiplin & $\begin{array}{l}\text { Tindakan yang menunjukan perilaku tertib dan patuh kepada setiap } \\
\text { peraturan yang telah dibuat. Bertujuan untuk mengembangkan diri agar } \\
\text { dapat perilaku tertib dan patuh. }\end{array}$ \\
\hline 5 & Kerja keras & $\begin{array}{l}\text { Sikap dan perilaku yang menunjukan upaya bersungguh-sungguh dalam } \\
\text { mengatasi sebuah hambatan yang dihadapi baik dalam hambatan tugas } \\
\text { maupun hambatan dalam belajar. Tujuan karakter ini adalah agar tidak } \\
\text { pantang menyerah dalam meraih yang diharapkan. }\end{array}$ \\
\hline 6 & Kreatif & $\begin{array}{l}\text { Berpikir dan melakukan sesuatu untuk menghasilkan cara atau hasil } \\
\text { yang baru yang telah dimiliki sebelumnya atau menciptakan sesuatu } \\
\text { yang baru yang belum pernah ada sebelumnya. }\end{array}$ \\
\hline 7 & Mandiri & $\begin{array}{l}\text { Sikap dan perilaku yang tidak tergantung pada orang lain baik dalam } \\
\text { menyelesaikan tugas sekolah maupun menyelesaikan tugas-tugas lain. }\end{array}$ \\
\hline 8 & Demokrasi & Cara bepikir, bersikap dan bertindak dengan sama-sama menilai hak dan \\
\hline
\end{tabular}




\begin{tabular}{|c|c|c|}
\hline & & $\begin{array}{l}\text { kewajiban dirinya dan orang lain. tujuannya adalah untuk saling } \\
\text { menumbuhkan sikap saling mengrhargai pada setiap siswa lain agar } \\
\text { lebih bijaksana dalam memaknai setiap peristiwa. }\end{array}$ \\
\hline 9 & Rasa ingin tahu & $\begin{array}{l}\text { Sikap dan tindakan yang berupaya untuk mengetahui lebih mendalam } \\
\text { dan meluas dari sesuatu yang dipelajari, dilihat dan didengar. }\end{array}$ \\
\hline 10 & $\begin{array}{l}\text { Semangat } \\
\text { kebangsaan }\end{array}$ & $\begin{array}{l}\text { Cara berpikir, bertindak dan berwawasan yang mana ia menempatkan } \\
\text { kepada kepentingan baik bangsa dan negara di atas diri sendiri dan } \\
\text { kelompoknya. }\end{array}$ \\
\hline 11 & Cinta tanah air & $\begin{array}{l}\text { Cara berpikir, bersikap, bertindak serta berbuat yang mana menunjukan } \\
\text { kesetian, kepedulian dan penghargaan yang setinggi-tingginya terhadap } \\
\text { bangsa, negara, lingkungan sosial, budaya, ekonomi maupun polotik. }\end{array}$ \\
\hline 12 & $\begin{array}{l}\text { Menghargai } \\
\text { prestasi }\end{array}$ & $\begin{array}{l}\text { Sikap dan tindakan yang mendorong dirinya untuk menghasilkan sesuatu } \\
\text { yang tidak hanya bermanfaat untuk dirinya namun juga bermanfaat } \\
\text { untuk orang lain, masyarakat, bangsa dan negara. Serta menghormati } \\
\text { dan menghargai setiap keberhasilan dan kesungguhan dari orang lain. }\end{array}$ \\
\hline 13 & $\begin{array}{l}\text { Bersahabat/ } \\
\text { komunikatif }\end{array}$ & $\begin{array}{l}\text { Bersahabat atau komunikati ini adalah sikap atau tindakan seseorang } \\
\text { yang mana memperlihatkan rasa senang bergaul, berbicara dan bekerja } \\
\text { sama dengan orang lain tanpa memandang fisik atau apapun. }\end{array}$ \\
\hline 14 & Cinta damai & $\begin{array}{l}\text { Sikap dan perkataan yang menyebabkan orang lain yang berada di } \\
\text { sekitar kita merasa senang dan aman jika adanya kehadiran kita dan } \\
\text { membenci permusuhan. }\end{array}$ \\
\hline 15 & $\begin{array}{l}\text { Gemar } \\
\text { membaca }\end{array}$ & $\begin{array}{l}\text { Kebiasaan yang positif yang mana menyediakan dan membutuhkan } \\
\text { waktu yang luang untuk membaca berbagai bacaaan yang memberikan } \\
\text { kebajikan bagi dirinya sendiri. }\end{array}$ \\
\hline 16 & $\begin{array}{l}\text { Peduli } \\
\text { lingkungan }\end{array}$ & $\begin{array}{l}\text { Perilaku, sikap dan tindakan yang selalu berupaya untuk mencegah } \\
\text { kerusakan pada lingkungan alam sekitar dan berusaha mengembangkan } \\
\text { upaya untuk memperbaiki setiap kerusakan yang telah terjadi dan } \\
\text { terlihat. }\end{array}$ \\
\hline 17 & Peduli sosial & $\begin{array}{l}\text { Sikap dan tindakan yang dirinya selalu ingin membantu dan memberikan } \\
\text { bantuan kepada orang lain yang sangat membutuhkan. Yang mana } \\
\text { bertujuan agar tidak hanya memperdulikan diri sendiri namun } \\
\text { memperdulikan orang lain pula. }\end{array}$ \\
\hline 18 & Tanggung jawab & $\begin{array}{l}\text { Sikap dan perilaku yang harus diterima dalam melaksanaan tugas dan } \\
\text { kewajibannya yang seharusnya dilakukan dan dikerjakan terhdap diri } \\
\text { sendiri, masyarakat, lingkungan, negara dan Tuhan Yang Maha Esa. }\end{array}$ \\
\hline
\end{tabular}




\section{Nilai-nilai Pendidikan Karakter serta Membina Karakter Siswa MI melalui Novel Anak- anak Langit Karya Mohd Amin MS}

Pendidikan karakter tidak cukup jika hanya diperkenalkan langsung oleh guru melalui mata pelajaran saja, akan tetapi jika diperkenalkan langsung melalui pengetahuan, perasaan serta perilakunya. Karya sastra atau novel itu sendiri muncul karena pengarang yang melihat langsung situasi dari kehidupan nyata, persoalan-persoalan yang dia lihat dan dicermati, sehingga dalam pembuatan novel ini pengarang tidak akan asal dalam pembuatannya. Novel merupakan salah satu dari berbagai macam karya sastra yang memiliki peran penting dan mengandung penerapan moral dalam sikap, perilaku dan tingkah laku setiap tokoh yang ada didalamnya, karena melalui tingkah laku, cerita, alur, serta kejadian yang ada di dalam novel yang mana diharapkan para pembaca tidak hanya menikmati jalan ceritanya namun dapat juga mengambil hikmah atau pelajaran dari pesanpesan moral yang disampaikan dan diamanatkan dalam novel tersebut (Harsono, 2014).

Dibawah ini akan dipaparkan dan dijelaskan nilai-nilai pendidikan karakter yang ada dalam novel anak-anak langit serta cara untuk menanamkan dan membina karakter tersebut siswa, yaitu:

\section{Religius}

Religius adalah sikap dan perilaku seseorang yang patuh dalam melaksanakan ajaran agama yang dianutnya serta toleran terhadap pelaksanaan agama lain. Sikap religius adalah sikap dimana seseorang yang akan melaksanakan apa yang sudah ditentukan tanpa adanya alasan yang menyebabkan seseorang tidak dapat melaksanakan perintahnya (Febrianshari et al., 2018).

Adapun kutipan yang ada didalam novel ini yang berkaitan dengan religius antara lain:

(1) "Pagi-pagi usai salat subuh, aku bergerak mengejar harapan itu." (p. hal.29)

(2) "Usai melaksanakan shalat zuhur lalu shalat rawatib, berdzikir dan berdoa. Sang Imam menyalami kami satu persatu” (hal.44)

Kutipan diatas menggambarkan tokoh-tokoh yang memiliki sikap religius yang taat terhadap perintah Allah yaitu salat dan berdoa, yang mana dari beberapa tokoh ini menggambarkan dengan jelas bahwa dalam setiap kegiatan, kesibukan dan sesakit apapun keadaan seseorang pada saat itu salat merupakan hal yang sangat dan yang harus dilakukan oleh seluruh Umat Islam. Sehingga dari kutipan ini dapat diterapkan dan ditanamkan kepada peserta didik untuk melakukan segala hal dimulai dan diakhiri dengan doa, dan dalam menerapkan ibadah solat kepada peserta didik adalah dengan melakukan pembiasaan melaksanakan shalat dhuha misalnya secara bersama-sama atau pembiasaan salat wajib seperti salat dzuhur berjamaah di sekolah dan dilakukan setiap hari, dan dapat diberikan sanksi kepada peserta didik yang tidak melakukannya.

\section{Jujur}

Nilai pendidikan karakter yang selanjutnya adalah jujur yang mana merupakan perilaku yang didasari dengan kepercayaan dalam perkataan maupun perbuatan, yang mana dengan adanya karakter jujur ini terkesan untuk selalu berkata jujur tanpa adanya dusta, penipuan dan lain sebagainya (Febrianshari et al., 2018). 
Adapun kutipan yang ada didalam novel ini yang berkaitan dengan jujur antara lain:

(1) “...... Kuputuskan untuk menceritakan apa yang terjadi, tentang keraguanku, kondisi Abah, dan pandangannya tentang etnis Tionghoa”. (hal.25)

(2) "Bapak ini orang manajemen yang sudah biasa jika menyerahkan sesuatu itu pada orang yang dipercaya" Ujar Pak Betrand kepada Simuh." (hal.390)

Dilihat dari penggalan-penggalan atau kutipan-kutipan diatas menggambarkan karakter jujur yang diterapkan beberapa tokoh seperti Simuh dan Pak Betrand yang mana mereka memiliki sikap jujur yaitu dengan mengatakan kebenaran agar semua dapat mempercayainya, karena jika seseorang telah mengatakan satu kali kejujuran maka jika ia mengatakan dan melakukannya kembali, maka orang-orang akan mempercayainya tanpa mencurigainya. Adapun teori serta kutipan diatas menggambarkan dengan jelas bagaiaman seseorang harus memiliki karakter jujur, dan adapun penerapannya dapat dilakukan ketika proses pembelajaran berlangsung ketika diadakannya ujian atau mengerjakan tugas/soal yang diberikan guru yang mana dalam pengerjaannya dapat dilakukan secara sendiri maupun kelompok yang mana setiap siswa memiliki kemampuan yang berbeda-beda. Dan dapat dilakukan pula dengan program kantin kejujuran yang disediakan di sekolah, yang mana melalui program ini siswa dilatih dan diberikan kebebasan untuk melakukan transaksi jual beli makanan maupun minuman serta melakukan pembayaran secara mandiri. Sehingga dari program ini, tugas seorang guru hanya mengawasi setiap siswa yang melakukan hal tersebut.

\section{Tanggung Jawab}

Nilai pendidikan karakter yang selanjutnya adalah tanggung jawab yang mana merupakan sikap dan perilaku yang harus diterima dalam setiap melaksanakan tugas dan kewajiban yang dilakukan, serta dikerjakan terhadap diri sendiri, masyarakat, lingkungan, Negara dan Tuhan Yang Maha Esa (Febrianshari et al., 2018).

Adapun kutipan yang menggambarkan tentang karakter tanggung jawab, antara lain:

(1) "Tugas utama kami adalah belajar dan memanfaatkan waktu” (hal.139)

(2) “......penyakitnya sudah parah, akan tetapi beliau memaksakkan diri untuk mengajar dan memnuhi tugas sebagai guru” (hal.380)

Orang yang memiliki tanggung jawab di dalam dirinya, maka ia akan terus melakukan yang terbaik agar tidak mengecewakan orang-orang yang telah mempercayainya. Orang yang bertanggung jawab tidak akan menyalahkan orang lain jika ia berbuat suatu kesalahan. Pada penggalan cerita diatas menjelaskan dari beberapa tokoh bahwa setiap orang memiliki tanggung jawab yang berbeda, dan harus menjalankannya sesuai dengan tugas yang diberikan. Tanggung jawab merupakan karakter yang harus ditanamkan kepada diri anak, agar ia memiliki rasa tanggung jawab baik dalam belajar, kegiatan di dalam rumah ataupun tanggung jawab yang ada di lingkungan sekitar atau masyarakat. Adapun penerapan yang dilakukan kepada siswa Madrasah Ibtidaiyah (MI) dapat dilakukan dengan melakukan kegiatan kerja kelompok yang mana setiap anak memiliki tugas yang berbeda-beda dalam setiap kelompok, sehingga mereka memiliki tugas 
dan tanggung jawab yang berbeda namun satu tujuan yaitu menyelesaikan tugasnya. Program/kegiatan ekstrakulikuler seperti drum band misalnya yang tentunya diharuskan melakukan kekompakan agar menghasilkan musik yang kompak dan bagus. Sehingga dari kedua kegiatan atau program itu dapat terlihat karakter tanggung jawab yang diinginkan.

\section{Toleransi}

Nilai pendidikan karakter yang selanjutnya adalah toleransi yang mana merupakan suatu sikap atau perilaku seseorang yang menghargai, menghormati segala bentuk dari setiap perbedaan setiap manusia dan setiap tindakan yang dilakukan oleh orang lain serta menghargai perbedaan baik dari pendapat, ras, suku, budaya maupun agama (Muawanah, 2018).

Adapun kutipan yang menggambarkan tentang toleransi yaitu:

Sebagai orang yang bijak, Mursalin tidak menunjukan gelagat untuk memprotes ucapan yang dikatakan oleh Pak Zainuddin."

Toleransi artinya mampu menerima dan menghargai setiap perbedaan pendapat yang berbeda dengan orang lain, tanpa menghakimi orang lain yang mengaitkannya dengan kebiasaanya, latar belakangnya maupun kondisinya. Negara Indonesia merupakan Negara yang multikultural yaitu seseorang yang hidup dalam keragaman yang banyak dan luas, serta kehidupan yang berbedabeda yang ada di dunia, maupun kebijakan kebudayaan yang menekankan tentang penerimaan terhadap adanya keragaman dan berbagai macam budaya. Sehingga penerapan yang dapat dilakukan kepada siswa dapat dilakukan ketika proses pembelajaran dengan memberi pengarahan dan pengertian kepada siswa untuk saling memahami, menghargai serta membantu siswa yang mengalami kesulitan belajar, serta memberikan pengarahan agar saling menghargai dan tidak membeda-bedakan. Dan saling menghargai jawaban setiap siswa lain.

\section{Disiplin}

Nilai pendidikan karakter yang selanjutnya ialah disiplin yaitu suatu tindakan atau perbuatan yang menunjukan perilaku tertib dan patuh terhadap setiap peraturan yang telah dibuat dan ditetapkan (Sanders \& Lukmansyah, 2017).

Adapun kutipan yang menggambarkan karakter disiplin dalam novel, antara lain:

(1) "Di Sekolah ini sangat ketat, mulai dari bangun tidur, belajar, sampai hukuman untuk keterlambatan dan kelalaian” Ujar Pak Hamdi. (hal.51)

(2) "Saya ingin kalian semua berbicara bahasa arab di asrama ini,....." ujar Pak Amri. (hal.73)

Disiplin sangat penting dan diperlukan oleh peserta didik, karena itu disiplin harus ditanamakan terus-menerus agar menjadi kebiasaan bagi peserta didik. Disiplin juga dapat menimbulkan rasa aman dan nyaman, contohnya adalah menegakkan aturan atau disiplin dalam lingkungan sekolah ketika proses pembelajaran, jika mentaati setiap peraturan ketika pembelajaran maka bukan hanya siswa yang akan merasa aman dan nyaman, namun sekolah tempat belajarnya pun akan merasakan hal yang sama. Seperti yang dicontohkan oleh tokoh diatas, untuk 
menggunakan bahasa arab dalam kesehariannya. Sehingga jika dilakukan dan digunakan setiap hari secara teratur maka akan jadi suatu disiplin yang menjadi kebiasaan yang bermanfaat dam pelajaran bagi yang melakukannya. Adapun dalam penerapannya dapat dilakukan dengan membiasakan kepada siswa untuk selalu tepat waktu ketika masuk kelas/sekolah dan akan diberikan sanksi jika ada yang terlambat. Tidak hanya itu ketika kegiatan upacara atau pramuka yang mana dalam kegiatannya peserta didik diminta untuk memakai perlengkapan yang rapih dan lengkap. Dan yang terakhir dapat dilakukan program rebo nyunda misalnya, yang mana setiap hari rabu siswa dibiasakan untuk menggunakan pakaian dan berbicara dengan menggunakan bahasa sunda.

\section{Kerja keras}

Nilai pendidikan karakter yang selanjutnya adalah bekerja keras yang mana merupakan suatu perilaku yang menunjukkan upaya sungguh-sungguh dalam mencapai kesukesasan yang mana seseorang yang tidak mengenal rasa putus atas dan kerja keras merupakan seseorang yang menghargai waktunya (Warih, 2014).

Adapun kutipan yang menggambarkan karakter kerja keras, yaitu:

(1) "Aku juga salut pada Thomas Alfa Edison. Meski dicap anak idiot, berkat ketekunannya, ia berhasil menciptakan bola lampu pijar, menjadikan hidup lebih mudah karenanya". (hal.20)

(2) "Pagi,siang, sore hingga malam kuhabiskan untuk belajar, karena tujuanku adalah mendapat prestadi dan tampil ke depan di lapangan sekolah" (hal.417)

Bekerja keras merupakan salah satu karakter yang harus tertanam dalam diri siswa karena dengan bekerja keras seorang siswa akan mampu mengembangkan potensi yang dimiliki oleh dirinya baik itu minat, bakat, maupun pengetahuaannya. Kerja keras dapat dilakukan oleh siapapun, bahkan orang yang tidak pandai sekalipun jika menginginkan nilai dan hasil yang baik dalam belajar, maka ia harus tekun, giat dan selalu meluangkan waktu untuk belajar. Seperti yang dilakukan oleh beberapa tokoh diatas yang mana dengan kerja keras, ketekunan, dan keinginannya mereka dapat mewujudkan apa yang mereka impikan. Dari kutipan diatas, maka dapat diterapkan kepada siswa untuk belajar dengan sungguh-sungguh, semangat dan kerja keras dalam mendapatkan nilai yang diinginkan dan memperoleh hasil yang maksimal. Tidak hanya itu penerapan dapat dilakukan dengan melakukan kegiatan seperti mengahafal al-quran bagi siswasiswa yang ingin, dari inilah guru dapat memberikan metode yang dikira siswa mampu atau siswa dapat mengahafal sesuai dengan bakat dan kemampuannya. Sehingga dari sinilah dapat terlihat siswa-siswa yang bekerja keras untuk menghafal sesuai target dan kemampuan dalam menghafalnya.

\section{Kreatif}


Nilai pendidikan karakter yang selanjutnya adalah kreatif yang merupakan berpikir dan melakukan sesuatu untuk menghasilkan cara atau hasil yang baru yang telah dimiliki sebelumnya atau menciptakan sesuatu yang baru yang belum pernah ada sebelumnya (Febrianshari et al., 2018).

Adapun kutipan yang menggambarkan karakter kreatif, antara lain:

(1) "Azwar memiliki cara unik dalam belajar. Dia memetakan semua pelajaran yang diingat dan dihafal" (hal.178)

(2) "Ketika belajar geografi tentang lempeng, gempa ataupun tsunami, ia selalu sibuk menggambar peta bumi yang dilengkapi dengan lapisan tanah, ....." Ujar Simuh. (hal.189)

Kreativitas itu sendiri memerlukan dua proses yaitu proses berpikir lalu proses memproduksi. Seseorang yang kreatif akan membuat hidup menjadi lebih mernarik dan tidak monoton, orang yang kreatif akan dikelilingi dengan sesuatu yang bervariasi akan lebih termotivasi dalam berbagai hal dan lebih bersemangat dalam mengerjakan sesuatu. Seseorang yang kreatif akan memiliki ide-ide yang baru dan mampu menghasilkan serta menciptakan sesuatu yang baru atau memperbaharui yang sudah ada menjadi sesuatu yang lebih menarik. kedua tokoh ini samasama memiliki ide cemerlang dalam memperoleh hasil belajar, yang mana kedua tokoh ini memiliki ide dan cara yang unik dalam belajar dengan menuangkan materi-materi pelajaran yang ia ingat, pelajari, dan didengar dalam bentuk kreasi mereka masing-masing. Adapun penerapannya adalah ketika guru mengajarkan, memberikan, serta meminta siswa untuk membuat sebuah kreasi dari sebuah rantai pohon, jagung, biji-bijian yang mana dari bahan-bahan itulah guru dapat meminta siswa membat kreasi dari berbagai karya apapun,, misalnya membuat bingkai foto dengan biji-bijian dan lain sebagainya.

\section{Mandiri}

Nilai pendidikan karakter yang selanjutnya adalah mandiri yang merupakan sebuah sikap dan perilaku seseorang yang kehidupanya tidak bergantung pada orang lain baik dalam menyelesaikan tugas sekolah, tugas rumah atau tugas-tugas lainya (Febrianshari et al., 2018).

Adapun kutipan yang menggambarkan karakter mandiri, yaitu:

"Mulai dari menyiapkan pakaian, memasukkan kedalam tas, berpamitan kepada omak, kakak, dan adiknya. Semua kulalui tanpa melawan sedikit pun." (hal.37)

Orang yang mandiri akan mampu menyelesaikan masalah yang sedang dihadapinya dan mencari jalan keluar atas masalahnya. Memiliki sikap mandiri berarti dapat menanam rasa tanggung jawab, berpikir secara lebih kritis, dapat memecahkan masalah oleh dirinya sendiri, memiliki banyak ide dalam berbagai tugas yang dimiliki dan yang paling penting tidak bergantung kepada orang lain. Sehingga untuk menjadikan siswa memiliki kepribadian mandiri dalam dirinya adalah dengan membiarkan, mengawasi serta membiasakan siswa dalam mengerjakan tugas sendiri tanpa bantuan orang lain, karena dari belajar secara mandiri itu akan memperoleh atau mendapatkan pengembagan dan keterampilan dalam dirinya. Adapun penerapanya adalah dengan membiarkan siswa untuk mencari materi pelajaran sendiri, mengerjakan tugas sendiri, dan 
melakukan kegiatan seperti membersikan dan merapihkan tas serta perlengkapan lainnya tanpa dibantu oleh orang lain.

\section{Rasa ingin tahu}

Nilai pendidikan karakter yang selanjutnya adalah rasa ingin tahu yang artinya tingkah laku seseorang untuk mengetahui dan akan mencari tahu terhadap suatu permasalahan yang sedang dihadapi atau cara berpikir dan bersikap yang mencerminkan rasa penasaran terhadap sesuatu yang dilihat, didengar maupun dipelajari (Fauzi, Zainuddin, \& Atok, 2017).

Adapun kutipan yang menggambarkan karakter rasa ingin tahu, antara lain:

(1) "Aku ingin mengetahui semua hal yang berkaitan dengan manusia, alam semesta, dan bagaimana semuanya dapat berkembang......"(hal.2)

(2) "Menurutmu dalam menjalani kehidupan ini, mana yang tepat. Mengikuti akal, logika, atau utamakan Wahyu dalam setiap hal?" (hal.75)

Rasa ingin tahu atau sering disebut rasa penasaran terhadap sesuatu yang dilihat atau didengar merupakan sesuatu yang dikatakan sulit dilakukan karena ketakutan dan keraguan yang dimiliki, tidak yakin untuk menanyakannya. Setiap orang atau peserta didik biasanya memiliki rasa atau hasrat ingin mengetahui namun dengan keterbatasannya, dengan ketakutan, keraguannya dan rasa tidak percaya diri karena takut jika apa yang ditanyakan tidak penting atau tidak berbobot, itulah yang akan membuat dirinya menjadi menyembunyikan rasa keingintahuannya itu. kutipan ini tergambar jelas bahwa mereka tidak ada sama sekali keraguan ataupun ketakutan dalam menanyakan yang ingin mereka ketahui. Mereka justru merasa bahwa apa yang mereka ingin ketahui ini dapat menambah wawasan yang lebih mendalam, sehingga mereka berani untuk menanyakan apa yang tidak mereka ketahui dan mereka mencari tahu dari berbagai sumber.

\section{Bersahabat/Komunikatif}

Nilai karakter yang selanjutnya adalah bersahabat atau komunikatif yang mana merupakan sikap dan perilaku seseorang yang senang bergaul, berbicara, serta bekerja sama dengan siapa saja (Rizki Kurniawati, 2018).

Adapun kutipan yang menggambarkan karakter bersahabat/komunikatif, antara lain:

“ Uangku memang kurang, tapi akan kutambah dengan wesel dari kampung. Aku ingin mereka merasakan gorengan ubi jalar....."(hal.234)

Orang yang memiliki sikap bersahabat dengan siapa saja akan mudah memahami setiap perilaku, sikap, serta pikiran dari orang yang berbeda. Orang yang bersahabat dengan siapa saja akan mudah mendapatkan teman-teman yang baru, memudahkan seseorang untuk saling bekerja sama dalam melakukan suatu hal yang dianggap sulit untuk dikerjakan sendiri. Bersahabat yang berarti mau mengenal siapapun, tanpa memandang atau membandingkan dengan siapapun. Adapun penerapan dapat melalui program tegur sapa.

\section{Semangat kebangsaan}


Nilai karakter yang selanjutnya ialah Cara berpikir, bertindak dan berwawasan yang mana ia menempatkan kepada kepentingan baik bangsa dan negara di atas diri sendiri dan kelompoknya (Rizki Kurniawati, 2018).

Adapun kutipan yang menggambarkan karakter semangat kebangsaan, yaitu:

"Maka kami bentuk pengurus asrama, mulai dari piket kebersihan, ketertiban, keamanan dan lain sebaginya. Dan menunjuk Andi sebagai ketua asrama kelas l"'(hal.131)

Peserta didik yang memiliki semangat kebangsaan dapat diwujudkan dengan adanya rasa patriotisme dan nasionalisme yang tinggi. Seseorang yang memiliki sikap ini akan terus mendukung Negaranya, dan selalu memprioritaskan kepentingan orang lain, bangsa dan negaranya. Adapun beberapa contoh semangat kebangsaan di lingkungan sekolah seperti dengan selalu menjaga nama baik sekolah, melakukan kegiatan sekolah, membantu kegiatan sekolah, ikut andil dalam organisasi sekolah, tidak melakukan tindakan anarkis, tidak melakukan tawuran, menjaga lingkungan sekolah dan lain sebagainya. Sehingga adapun contoh penerepan yang dapat dilakukan adalah kegiatan upacara yang dilakukan secara khidmat dan meminta siswa untuk mengikuti berbagai organisasi atau kegiatan-kegiatan yang ada di sekolah.

\section{Cinta damai}

Nilai karakter yang selanjutnya ialah cinta damai yang merupakan sikap, perilaku dan perkataan yang menyebabkan orang lain yang berada di sekitar kita merasa senang, aman dan nyaman jika adanya kehadiran kita di sekitarnya dan membenci permusuhan (Khairunnisa, 2015).

Adapun kutipan novel yang menggambarkan karakter cinta damai, antara lain:

"...... Ang Cui selalu berpesan untuk mengubur permusuhan dan dendam itu dalamdalam, jangan melihat ke belakang” Nadanya lirih. (hal.111)

Untuk mewujudkan sikap cinta damai ini tidak hanya dari perbuatan atau tindakan, namun juga dari perkataan yang harus selalu dijaga ketika berbicara dengan orang lain. Sehingga untuk menerapkan cinta damai kepada peserta didik dapat dicontohkan dengan tidak memiliki rasa dendam kepada sesama manusia lain, mengajarkan mereka untuk tidak saling membedabedakan yang akan membuat seseorang tersinggung, dan mengajarkan anak untuk tidak memiliki rasa iri kepada siapa pun.

\section{Cinta tanah air}

Nilai karakter yang berikutnya yang ada di dalam novel adalah cinta tanah air yang merupakan cara berpikir, bersikap, bertindak serta berbuat yang mana menunjukan kesetian, kepedulian dan penghargaan yang setinggi-tingginya terhadap bangsa, negara, lingkungan sosial, budaya, ekonomi maupun politik (Khairunnisa, 2015).

Adapun kutipan yang menggambarkan karakter cinta damai, yaitu:

(1) “...... Saat melihat tayangan Al-Jazeera. Memoriku melayang pada saat paling dramatis diasrama dulu.....” (hal.2) 
(2) “....kendati batas terotorial dan kedaerahan sudah terabaikan. Namun tetap ada rasa bangga membawa nama daerah" (hal.4)

Seseorang yang memiliki rasa cinta terhadap tanah air sendiri akan selalu membela negaranya, memakai produk-produk buatan negara sendiri, selalu mengingatnya kemana dan dimanapun ia tinggal. Seperti yang dicontohkan kedua tokoh ini, mereka masih mengingat dan membangga-banggakan tempat kelahirannya walaupun mereka sedang berjuang meraih impian di negeri atau kota orang. Dengan begitu, darinya harus belajar bahwa sejauh apapun pendidikan yang kita lakukan, namun tetap harus mengingat tempat awal kita dilahirkan. Adapun dalam penerapannya kepada anak Madrasah Ibtidaiyah (MI), agar mereka memiliki karakter cinta tanah air yaitu dengan melakukan upacara dengan khidmat dengan mengenang segala jasa para pahlawan, sikap selalu menghargai dan mencintai setiap produk Indonesia, selalu menggunakan bahasa Indonesia yang baik, yang bertujuan untuk menunjukkan bahwa siswa menghargai serta mencintai tanah air sendiri.

\section{Peduli Sosial}

Nilai karakter yang berikutnya adalah peduli sosial yang berarti sikap dan tindakan yang dirinya selalu ingin membantu dan memberikan bantuan kepada orang lain yang sangat membutuhkan (Fauzi et al., 2017).

Adapun kutipan novel yang menggambarkan karakter peduli sosial, yaitu:

"Mereka membentuk komunitas tersendiri dan menjadikan daerah baru ini sebagai tempat mencari nafkah yang memakmurkan" (hal.17)

Sikap inilah yang akan membantu negara ini menjadi lebih baik, karena saling memberikan bantuan, saling bergotong royong untuk membantu yang sangat membutuhkan, dengan adanya sikap ini seseorang tidak akan merasa kesulitan dan kesusahan orang lain, orang yang membatu justru meringankan beban dan segala kesulitan yang dialami. Peduli sosial tidak perlu membantu dengan materi saja namun dapat menggunakan tenaga agar pekerjaan orang lain lebih ringan. Seperti yang dicontohkan kutipan diatas, saling membantu terhadap ekonomi lingkungan sekitarnya. Adapun penerapan yang dapat dilakukan salah satunya adalah dengan melakukan kegiatan yang direncanakan oleh pihak sekolah, seperti membantu orang-orang yang tidak mampu dengan hasil dan kerja keras mereka, atau menggunakan penggalangan dana untuk orangorang yang terkena musibah dan yang tidak mampu, dari kegiatan ini dapat dilihat bagaimana cara siswa memperlakukan orang-orang yang tidak mampu dan cara mereka untuk membantu orang-orang yang tidak mampu.

\section{Menghargai Prestasi}

Nilai karakter yang berikutnya adalah menghargai prestasi yang artinya sikap dan tindakan seseorang yang mendorong dirinya untuk menghasilkan sesuatu yang tidak hanya bermanfaat bagi 
dirinya, namun juga bermanfaat bagi orang masyarakat banyak. Serta dapat menghormati dan menghargai setiap keberhasilan dan kesungguhan yang dimiliki oleh orang lain (Evenddy, 2017).

Adapun kutipan novel yang menggambarkan karakter menghargai prestasi, antara lain:

(1) "Pak Iskandar tidak sekedar memuji prestasiku, tapi ia memberiku hadian uang tunai" (hal.13)

(2) "Aku memilih syafrizal, anak hebat dengan nilai tertinggi sekabupaten" (hal.63)

Menghargai prestasi orang lain dapat berupa pujian atau ucapan selamat yang dapat meningkatkan semangat kepada orang yang mendapat sebuah prestasi dan juga memberikan motivasi untuk orang yang memujinya. Seseorang yang dapat menghargai prestasi orang lain akan terus berupaya secara maksimal untuk meraih hal yang sama serta meraih apa yang dicitacitakannya. Dari kutipan ini mencontohkan bagaimana seseorang yang memuji dan menghargai prestasi yang dimiliki oleh orang lain. Sehingga dalam penerapannya daapat dilakukan ketika proses pembelajaran dimulai dari guru yang selalu memberikan pujian, ataupun hadiah kepada siswa yang memiliki nilai baik, sehingga akan membuat siswa lain menjadi termotivasi.

\section{Gemar membaca}

Nilai karakter yang selanjutnya adalah gemar membaca yang berarti kebiasaan positif yang mana menyediakan dan membutuhkan waktu yang luang untuk membaca berbagai jenis buku bacaan yang memberikan wawasan dan kebijakan bagi dirinya sendiri (Surakarta, n.d.).

Adapun kutipan yang menggambarkan karakter gemar membaca, antara lain:

(1) "Rasyid, misalnya, masih asyik dengan kitab-kitabnya." (hal.3)

(2) “Aku pernah membaca riwayat Ibnu Batutah dan Colombus....." (hal.15)

Gemar membaca merupakan langkah awal untuk mencerdaskan bangsa dan orang yang gemar membaca akan memiliki wawasan yang luas serta kreatifitas yang tinggi serta menjadikan siswa menjadi manusia yang banyak akal. Siswa yang gemar membaca akan menguasai banyak kata, kalimat dan mempelajari berbagai jenis kalimat serta dapat meningkatkan memori otak siswa. Siswa yang gemar membaca berarti menjernihkan serta mengembangkan pemikirannya yang dapat meningkatkan kemampuan seseorang dalam pengetahuannya. Adapun dapat diterapkan kepada siswa jika lingkungan yang ia tinggali merasa nyaman, seperti memberikan fasilitas untuk membaca (perpustakaan) yang mana guru dapat menyediakan perpustakaan yang rapih, nyaman dan bersih sehingga ia akan fokus dalam membaca dan akan lebih sering melakukan kegiatan membaca karena tempat yang ia tinggali nyaman untuk belajar. Dan dapat juga seperti kegiatan atau program seperti pojok baca yang dilakukan selama kurang lebih 15 menit.

\section{Demokratis}

Nilai karakter yang selanjutnya adalah demokratis yang artinya cara berpikir, bersikap dan bertindak dengan sama-sama menilai hak dan kewajiban dirinya dan orang lain (Evenddy, 2017)

Adapun kutipan novel yang menggambarkan karakter demokratis, yaitu: 
"Marilah jaga hak kawan yang lalin, seberapalah kuat perut kita" ujarnya lirih. (hal.147).

Demokratis akan menumbuhkan rasa kebersamaan, memupuk rasa saling menghargai antar sesama, memiliki rasa empati dan rasa kasih sayang antar sesama manusia, juga terhindar dari halhal yang tidak diinginkan seperti adanya kekerasan, perkelahian maupun kekerasan dan mampu menjalin komunikasi yang baik antar sesama. Dalam kutipan ini menggambarkan bagaimana salah satu tokoh yang menghargai dan memperlakukan orang sama, bahwa seseorang harus saling menjaga hak sesama, dan tidak membeda-bedakan atau melebihkan apapun yang seharusnya tidak boleh dilebihkan.

\section{Peduli Lingkungan}

Nilai karakter yang selanjutnya adalah peduli lingkungan yang artinya Perilaku, sikap dan tindakan yang selalu berupaya untuk mencegah kerusakan pada lingkungan alam sekitar dan berusaha mengembangkan upaya untuk memperbaiki setiap kerusakan yang telah terjadi dan terlihat (Surakarta, n.d.).

Adapun kutipan novel yang menggambarkan nilai karakter peduli lingkungan, yaitu:

(1) "Ada beberapa aturan, untuk tidak membuang sampah, merusak pepohonan, berbuat onar dan tidak boleh membawa Edelwish" (hal.422)

(2) "Ku mengingatnya, benar-benar peringatan untuk menjaga kelangsungan lingkungan di Singgalang". (hal,425)

Peduli lingkungan berarti mendorong siswa kepada kebiasaan-kebiasaan yang dilihat di lingkungan sekitar seperti mengelola lingkungan sekitar, memupuk kepekaan terhadap lingkungan, bertanggung jawab terhadap lingkungan dan peserta didik harus menjadi contoh dalam penyelamatan lingkungan. Adapun kegiatan atau program yang dapat menerapkan karakter peduli lingkungan adalah melakukan kegiatan kerja bakti untuk membersihkan lingkungan sekolah, atau dapat juga melakukan kebersihan setelah jam pelajaran selesai.

\section{KESIMPULAN DAN SARAN}

1. Pendidikan karakter dalam novel Anak-anak langit

Nilai-nilai pendidikan karakter yang terdapat dalam novel Anak-anak Langit Karya Mohd Amin Ms yaitu nilai karakter religius, jujur, tanggungjawab, disiplin, bekerja keras, kreatif, mandiri, rasa ingin tahu, gemar membaca, menghargai prestasi, demokratis, peduli sosial, bersahabat/komunikatif, toleransi, semangat kebangsaan, cinta tanah air, cinta damai dan peduli lingkungan. Sehingga dapat dikatakan bahwa didalam novel Anak-anak Langit ini memiliki keseluruhan dari pendidikan nilai-nilai karakter.

2. Nilai-nilai Karakter dalam Novel Anak-anak Langit untuk diterapkan di Madrasah Ibtidaiyah (MI) 
Novel Anak-anak Langit Karya Mohd Amin Ms ini bisa dijadikan sebagai salah satu sumber untuk menerapkan karakter kepada siswa, yang mana dalam penerapannya nilai-nilai pendidikan karakter ini dapat diterapkan melalui program atau kegiatan yang ada didalam sekolah seperti kegiatan-kegiatan rutin yang dapat dijadikan kebiasaan dan pembiasaan kepada siswa. Dan dapat diterapkan melalui kegiatan atau program ekstrakulikuler dan intrakulikuler.

Menyadari banyak sekali kekurangan dalam penelitian ini, maka kami mengharap kritik serta saran dari para pembaca untuk melengkapi segala kekurangan dan kesalahan. Sehingga penelitian ini dapat menjadi kontribusi yang nyata dalam pengembangan ilmu khususnya dalam perubahan karakter untuk anak MI.

\section{DAFTAR PUSTAKA}

Ernawati, Y. (2019). Membangun Karakter Melalui Pembelajaran Sastra: Problematika Pembinaan Karakter. Jurnal Ilmiah Bina Edukasi, 11(01), 49-59. https://doi.org/10.33557/jedukasi.v11i01.205

Evenddy, S. S. (2017). PENDIDIKAN KARAKTER. 3, 47-52.

Fauzi, A. R., Zainuddin, Z., \& Atok, R. Al. (2017). Penguatan Karakter Rasa Ingin Tahu dan Peduli Sosial melalui Discovery Learning. Jurnal Teori Dan Praksis Pembelajaran IPS, 2(2), 79-88. https://doi.org/10.17977/um022v2i22017p079

Febrianshari, D., Kusuma, V. C., Jayanti, N. D., Ekowati, D. W., Prasetya, M. Y., \& Suwandayani, I. (2018). ANALISIS NILAI-NILAI PENDIDIKAN KARAKTER. 6(April), 88-95.

Khairunnisa. (2015). ( Studi Analisis Kompetensi Dasar Mata Pelajaran IPA MI pada Kurikulum 2013 ) The Mapping of National Character in Science Concept of MI ( Analysis Study on the Basic Competence of Science Subject of MI in Curriculum 2013 ). 67-72.

Mirzaqon, A., \& Purwoko, B. (2018). Studi Kepustakaan Mengenai Landasan Teori Dan Praktik Konseling Expressive Writing Library. Jurnal BK UNESA, (1), 1-8.

Muawanah. (2018). Pentingnya Pendidikan untuk Tanamkan Sikap Toleran di Masyarakat. Jurnal Vijjacariya, 5(1), 57-70. https://doi.org/10.31219/osf.io/vqgj4

MS, M. A. (2011). Anak-anak Langit. Jakarta: Pustaka Alvabet.

Nopan, O. (2015). Pentingnya Pendidikan Karakter Dalam Dunia Pendidikan. 9(manager pendidikan), 464-468.

Putry, R. (2019). Nilai Pendidikan Karakter Anak Di Sekolah Perspektif Kemendiknas. Gender Equality: International Journal of Child and Gender Studies, 4(1), 39. https://doi.org/10.22373/equality.v4i1.4480

Rizki Kurniawati, I. (2018). Analisis Nilai Karakter Dalam Teks Cerita Buku Pelajaran Siswa Sekolah Dasar. Jurnal Master Bahasa, 6(2), 103-114.

Samrin. (2016). Pendidikan karakter (sebuah pendekatan nilai). Jurnal Al-Ta'dib, 9(1), 120-143.

Sanders, M. G., \& Lukmansyah, D. (2017). Jurnal Manajemen, Kepemimpinan, dan Supervisi 
Pendidikan Volume 1, No. 1, Juli-Desember 2017. American Journal of Education, 1(2), 233-255. https://doi.org/10.1086/674374

Sholichah, A. S. (2018). Jurnal Edukasi Islami Jurnal Pendidikan Islam Vol . 07 / No . 1, TeoriTeori Pendidikan ... Teori-Teori Pendidikan .... Jurnal Pendidikan Islam, 07(1), 23-46. https://doi.org/10.30868/EI.V7

Sidiq, U., \& Choiri, M. M. (2019). Metode Penelitian Kualitatif di Bidang Pendidikan. Ponorogo: CV Nata Karya .

Surakarta, D. S. (n.d.). Character Education Value in the Expression of Hikmah in the.

Sugiyono. (2017). Metode Penelitian Kuantitatif, Kualitatif dan R \& D. Bandungg: Alfabeta.

Syah, M. (2010). Psikologi Pendidikan dengan Pendekatan Baru. Bandung: PT Remaja Rosdakarya

Syukwansyah, D. (2016). Pengembangan Bisnis Joeragan Dengan Menggunakan Pendekatan Prinsip Efektual. Performa, 1. Retrieved from http://journal.uc.ac.id/index.php/performa/article/view/137

Utomo, C. B., \& Muntholib, A. (2018). Implementasi Pendidikan Karakter dalam Membentuk Sikap dan Perilaku Sosial Peserta Didik Melalui Pembelajaran Sejarah di SMA PGRI 1 Pati Tahun Pelajaran 2017/2018. Indonesian Journal of History Education, 6(1), 1-13.

Wandi, \& Nurhasono. (2013). Pembinaan Prestasi Ekstrakurikuler Olahraga Di Sma Karangturi Kota Semarang. Active - Journal of Physical Education, Sport, Health and Recreation, 2(8), 524-535. https://doi.org/10.15294/active.v2i8.1792

Warih, N. (2014). Upaya Orang Tua dalam Menanamkan Karakter Kerja Keras Anak Usia Remaja di Dusun Tegalyoso Banyuraden Gamping Sleman Yogyakarta. Upaya Orang Tua Dalam Menanamkan Karakter Kerja Keras Anak Usia Remaja Di Dusun Tegalyoso Banyuraden Gamping Sleman Yogyakarta, 4(1), 27-38. https://doi.org/10.12928/citizenship.v4i1.628. 